\title{
Tumor suppressive microRNA-138 contributes to cell migration and invasion through its targeting of vimentin in renal cell carcinoma
}

\author{
TAKESHI YAMASAKI ${ }^{1}$, NAOHIKO SEKI ${ }^{2}$, YASUTOSHI YAMADA ${ }^{1}$, HIROFUMI YOSHINO $^{1}$, \\ HIDEO HIDAKA $^{1}$, TAKESHI CHIYOMARU ${ }^{1}$, NIJIRO NOHATA ${ }^{2}$, TAKASHI KINOSHITA ${ }^{2}$, \\ MASAYUKI NAKAGAWA ${ }^{1}$ and HIDEKI ENOKIDA ${ }^{1}$ \\ ${ }^{1}$ Department of Urology, Graduate School of Medical and Dental Sciences, Kagoshima University, Kagoshima; \\ ${ }^{2}$ Department of Functional Genomics, Graduate School of Medicine, Chiba University, Chiba, Japan
}

Received March 28,2012; Accepted May 30, 2012

DOI: 10.3892/ijo.2012.1543

\begin{abstract}
Many studies have recently suggested that microRNAs (miRNAs) contribute to the development of various types of human cancers as well as to their invasive and metastatic capacities. Previously, our miRNA expression signature of renal cell carcinoma (RCC) revealed that microRNA-138 (miR-138) was significantly reduced in cancer cells. The aim of the present study was to investigate the functional significance of $m i R-138$ and to identify its target genes in RCC cells. Restoration of mature miR-138 in two RCC cell lines (A498 and 786-O) caused changes in the bleb-like cell morphology, characteristics of the epithelial-mesenchymal transition (EMT). Restoration also significantly inhibited migration and invasion in the two RCC cell lines, suggesting that $m i R-138$ functions as a tumor suppressor. Genome-wide gene expression analysis ( $m i R-138$ transfectants and RCC clinical specimens) and TargetScan database studies showed that vimentin (VIM) is a promising candidate target gene of miR-138. It is well known that VIM is one of the most widely expressed mammalian intermediate filament proteins. Recent studies showed that VIM functions in cell adhesion, migration, survival and cell signaling processes via dynamic assembly/disassembly in cancer cells. We focused on VIM and investigated whether VIM was regulated by tumor suppressive $m i R-138$ and contributed to cancer cell migration and invasion in RCC cells. Restoration of miR-138 in RCC cell lines suppressed VIM expression at both the mRNA and protein levels. Silencing studies of VIM in RCC cell lines demonstrated significant inhibition of cell migration and invasion activities in si-VIM transfectants. In clinical specimens of RCC, the expression levels of VIM were significantly upregulated in cancer tissues
\end{abstract}

Correspondence to: Dr Hideki Enokida, Department of Urology, Graduate School of Medical and Dental Sciences, Kagoshima University, 8-35-1 Sakuragaoka, Kagoshima 890-8520, Japan

E-mail: enokida@m.kufm.kagoshima-u.ac.jp

Key words: microRNA, miR-138, vimentin, renal cell carcinoma compared to adjacent non-cancerous tissues. Furthermore, immunohistochemistry showed that VIM expression levels in RCC specimens were significantly higher than those in normal renal tissues. These data suggest that VIM may function as an oncogene and is regulated by tumor suppressive $m i R-138$. The existence of a tumor suppressive miR-138-mediated oncogenic pathway provides new insights into the potential mechanisms of RCC oncogenesis and metastasis.

\section{Introduction}

Renal cell carcinoma (RCC) is the most common neoplasm of the adult kidney. In this disease, cancer cells form in the tubules of the kidney and approximately $80 \%$ of RCC patients are diagnosed with the clear cell RCC subtype (1). Up to $30 \%$ of RCC patients present at advanced stages, and approximately $40 \%$ of patients who undergo curative surgical resection experience recurrence during subsequent follow-up $(2,3)$. The five-year survival rate of advanced RCC is $5-10 \%$ (4). RCC is resistant to radiotherapy and chemotherapy $(5,6)$. Targeted therapies such as sunitinib, sorafenib, everolimus and temsirolimus have been developed and have been used widely in first- and second-line treatments, extending the period of progression-free-survival $(7,8)$. However, these treatments are insufficient for patients who have developed relapse or metastasis. Therefore, increased understanding of the molecular mechanisms of RCC progression and metastasis is needed using the latest approaches to genomic analysis.

RNA can be divided into two categories: protein coding RNA and non-coding RNA (ncRNA). It is important to examine the functions of ncRNAs and their association with human disease, including cancer. microRNAs (miRNAs) are endogenous small ncRNA molecules (19-22 bases in length) that regulate protein coding gene expression by repressing translation or cleaving RNA transcripts in a sequence-specific manner (9). A growing body of evidence suggests that miRNAs are aberrantly expressed in many human cancers, and that they play significant roles in their initiation, development, and metastasis (10). Some highly expressed miRNAs could function as oncogenes by repressing tumor suppressors, whereas low level miRNAs could function as tumor suppressors by negatively regulating oncogenes (11). 
We previously identified many tumor suppressive miRNAs based on our miRNA expression signatures of various types of cancer, such as RCC, bladder cancer, prostate cancer, maxillary sinus squamous cell carcinoma and hypopharyngeal squamous cell carcinoma (12-17). In oncogenic pathways, normal regulatory mechanisms are disrupted by aberrant expression of tumor suppressive or oncogenic miRNAs. Therefore, identification of miRNA-regulated pathways is important for further development in human cancer research. Thus, we have been investigating how tumor suppressive miRNA regulates novel cancer pathways. For example, the $m i R-1 / m i R-133 a$ cluster regulates several oncogenic genes, including transgelin-2 (TAGLN2), prothymosin $\alpha$ (PTMA) and purine nucleoside phosphorylase $(P N P)(14,15,18)$.

More recently, we constructed a miRNA expression signature of RCC clinical specimens and successfully identified tumor suppressive miR-1285 targeting transglutaminase 2 (TGM2) (12). Among the signatures, several miRNAs were significantly downregulated in RCC specimens as promising candidate of tumor suppressors. In this study, we focused on miR-138. This miRNA was downregulated in our previous signature, and downregulation of $m i R-138$ has been observed in several malignancies, including anaplastic thyroid carcinoma (19) and lung cancer (20).

The aim of the study was to investigate the functional significance of $m i R-138$ and identify its target genes in RCC cells. To identify $m i R$-138-regulated cancer pathways, we undertook both a genome-wide gene expression analysis (miR-138 transfectants and RCC clinical specimens) and an in silico study. The results showed that vimentin (VIM) was a promising candidate target gene of $m i R-138$. It is well known that VIM is one of the most widely expressed mammalian intermediate filament proteins. Studies have shown that VIM functions in cell adhesion, migration, survival, and cell signaling processes via dynamic assembly/disassembly in cancer cells (21). The existence of a tumor suppressive miR-138-mediated cancer pathway provides new insights into the potential mechanisms of RCC oncogenesis and metastasis.

\section{Materials and methods}

Clinical specimens. A total of 33 pairs of clear cell renal cell carcinoma (ccRCC) and adjacent non-cancerous specimens were collected from patients who had undergone radical nephrectomies at Kagoshima University Hospital. The samples were processed and stored in RNAlater (Qiagen, Valencia, CA, USA) at $-20^{\circ} \mathrm{C}$ until RNA extraction. The patient information is summarized in Table I. These samples were staged according to the American Joint Committee on Cancer-Union Internationale Contre le Cancer (UICC) tumour-node-metastasis classification and histologically graded (22). Our study was approved by the Bioethics Committee of Kagoshima University; written prior informed consent and approval were given by the patients.

Cell culture and RNA extraction. We used two human RCC cell lines, A498 and 786-O, obtained from the American Type Culture Collection (Manassas, VA, USA). The cell lines were incubated in RPMI-1640 medium supplemented with $10 \%$ fetal bovine serum (FBS) and maintained in a humidified incubator $\left(5 \% \mathrm{CO}_{2}\right)$ at $37^{\circ} \mathrm{C}$. Total-RNA was extracted, as previously described (12).
Table I. Patient characteristics of RT-PCR experiments.

\begin{tabular}{lrr}
\hline \multicolumn{2}{c}{ No. of patients (\%) } \\
\hline Total number & 33 & \\
Age (average) & $36-83$ & $(65.6)$ \\
Gender & & \\
Male & 22 & $(66.7)$ \\
Female & 11 & $(33.3)$ \\
Pathological tumor stage & & \\
pT1a & 12 & $(36.4)$ \\
pT1b & 14 & $(42.4)$ \\
pT2 & 2 & $(6.1)$ \\
pT3a & 3 & $(9.1)$ \\
pT3b & 2 & $(6.1)$ \\
pT4 & 0 & $(0.0)$ \\
Grade & & \\
G1 & 5 & $(15.2)$ \\
G2 & 26 & $(78.8)$ \\
G3 & 0 & $(0.0)$ \\
Unknown & 2 & $(6.1)$ \\
Infiltration & & \\
$\alpha$ & 12 & $(36.4)$ \\
$\beta$ & 21 & $(63.6)$ \\
$\gamma$ & 0 & $(0.0)$ \\
Venous invasion & & \\
v (-) & 24 & $(72.7)$ \\
v (+) & 9 & $(27.3)$ \\
\hline
\end{tabular}

Quantitative real-time RT-PCR. TaqMan probes and primers for VIM (P/N: Hs00185584_m1: Applied Biosystems) were assay-on-demand gene expression products. All reactions were performed in duplicate, and a negative control lacking cDNA was included. We followed the manufacturer's protocol for PCR conditions. Stem-loop RT-PCR (TaqMan MicroRNA Assays; P/N: 002284 for miR-138; Applied Biosystems) was used to quantitate miRNAs according to the earlier published conditions (23). To normalize the data for quantification of VIM mRNA and the miRNAs, we used human GUSB (P/N: Hs99999908_m1; Applied Biosystems) and RNU6B (P/N: 001973; Applied Biosystems), respectively, and we used the $\Delta \Delta \mathrm{Ct}$ method to calculate the fold-change. As a control RNA, we used Premium total-RNA from normal human kidney (AM 7976; Applied Biosystems).

Mature miRNA and siRNA transfection. As described elsewhere (23), the RCC cell lines were transfected with Lipofectamine $^{\mathrm{TM}}$ RNAiMAX transfection reagent (Invitrogen, Carlsbad, CA, USA) and Opti-MEM ${ }^{\mathrm{TM}}$ (Invitrogen) with $10 \mathrm{nM}$ mature miRNA molecules. Pre-miR ${ }^{\mathrm{TM}}$ (Applied Biosystems) and negative-control miRNA (Applied Biosystems) were used in the gain-of-function experiments, whereas VIM siRNA (Cat nos. SASI_Hs01_00044033 and SASI_HS01_00044036, Sigma-Aldrich, St. Louis, MO, USA) and negative control siRNA (D-001810-10; Thermo Fisher Scientific, Waltham, MA, USA) were used in the loss-of-function experiments. Cells were seeded in $10-\mathrm{cm}$ dishes for protein extraction $\left(8 \times 10^{5}\right.$ cells per 
Table II. Downregulated genes in microRNA-138 transfectants.

\begin{tabular}{|c|c|c|c|}
\hline $\begin{array}{l}\text { Entrez } \\
\text { gene ID }\end{array}$ & Symbol & Average & $\begin{array}{c}\text { Target } \\
\text { site }\end{array}$ \\
\hline 3569 & IL6 & -5.35 interleukin 6 (interferon, $\beta$ 2) & $(-)$ \\
\hline 4856 & NOV & -5.22 nephroblastoma overexpressed gene & $(-)$ \\
\hline 84448 & ABLIM2 & -4.97 actin binding LIM protein family, member 2 & $(-)$ \\
\hline 3773 & KCNJ16 & -4.86 potassium inwardly-rectifying channel, subfamily $\mathrm{J}$, member 16 & $(-)$ \\
\hline 6352 & CCL5 & -4.44 chemokine (C-C motif) ligand 5 & $(-)$ \\
\hline 4316 & MMP7 & -4.1 matrix metallopeptidase 7 (matrilysin, uterine) & $(-)$ \\
\hline 3038 & HAS3 & -4.03 hyaluronan synthase 3 & $(+)$ \\
\hline 91543 & RSAD2 & -3.99 radical S-adenosyl methionine domain containing 2 & $(-)$ \\
\hline 5806 & PTX3 & -3.85 pentraxin-related gene, rapidly induced by IL-1 $\beta$ & $(-)$ \\
\hline 64220 & STRA6 & -3.85 stimulated by retinoic acid gene 6 homolog (mouse) & $(+)$ \\
\hline 84419 & C15orf48 & -3.8 chromosome 15 open reading frame 48 & $(-)$ \\
\hline 144406 & WDR66 & -3.67 WD repeat domain 66 & $(-)$ \\
\hline 4493 & MT1E & -3.66 metallothionein $1 \mathrm{E}$ & $(-)$ \\
\hline 718 & $\mathrm{C} 3$ & -3.65 complement component 3 & $(-)$ \\
\hline 10964 & IFI44L & -3.64 interferon-induced protein 44-like & $(-)$ \\
\hline 3990 & LIPC & -3.64 lipase, hepatic & $(-)$ \\
\hline 9121 & SLC16A5 & -3.61 solute carrier family 16, member 5 (monocarboxylic acid transporter 6 ) & $(-)$ \\
\hline 4490 & MT1B & -3.6 metallothionein $1 \mathrm{~B}$ & $(-)$ \\
\hline 8091 & HMGA2 & -3.56 high mobility group AT-hook 2 & $(-)$ \\
\hline 1803 & DPP4 & -3.49 dipeptidyl-peptidase 4 & $(-)$ \\
\hline 6288 & SAA1 & -3.48 serum amyloid A1 & $(-)$ \\
\hline 4502 & MT2A & -3.44 metallothionein $2 \mathrm{~A}$ & $(-)$ \\
\hline 8638 & OASL & -3.43 2'-5'-oligoadenylate synthetase-like & $(-)$ \\
\hline 9582 & APOBEC3B & -3.39 apolipoprotein B mRNA editing enzyme, catalytic polypeptide-like 3B & $(-)$ \\
\hline 4500 & MT1L & -3.32 metallothionein 1L (gene/pseudogene) & $(-)$ \\
\hline 3437 & IFIT3 & -3.3 interferon-induced protein with tetratricopeptide repeats 3 & $(-)$ \\
\hline 9076 & CLDN1 & -3.05 claudin 1 & $(-)$ \\
\hline 8743 & TNFSF10 & -3.03 tumor necrosis factor (ligand) superfamily, member 10 & $(-)$ \\
\hline 3433 & IFIT2 & -2.94 interferon-induced protein with tetratricopeptide repeats 2 & $(-)$ \\
\hline 2172 & FABP6 & -2.91 fatty acid binding protein 6 , ileal & $(-)$ \\
\hline 23586 & DDX58 & -2.89 DEAD (Asp-Glu-Ala-Asp) box polypeptide 58 & $(-)$ \\
\hline 4982 & TNFRSF11B & -2.89 tumor necrosis factor receptor superfamily, member $11 b$ & $(-)$ \\
\hline 259307 & IL4I1 & -2.88 interleukin 4 induced 1 & $(-)$ \\
\hline 6590 & SLPI & -2.88 secretory leukocyte peptidase inhibitor & $(-)$ \\
\hline 5174 & PDZK1 & -2.88 PDZ domain containing 1 & $(-)$ \\
\hline 51015 & ISOC1 & -2.86 isochorismatase domain containing 1 & $(+)$ \\
\hline 3434 & IFIT1 & -2.84 interferon-induced protein with tetratricopeptide repeats 1 & $(-)$ \\
\hline 22822 & PHLDA1 & -2.79 pleckstrin homology-like domain, family A, member 1 & $(-)$ \\
\hline 2537 & IFI6 & -2.76 interferon, $\alpha$-inducible protein 6 & $(-)$ \\
\hline 392636 & TMEM195 & -2.76 transmembrane protein 195 & $(-)$ \\
\hline 81610 & FAM83D & -2.73 family with sequence similarity 83, member D & $(+)$ \\
\hline 26154 & ABCA12 & -2.66 ATP-binding cassette, sub-family A (ABC1), member 12 & $(-)$ \\
\hline 4940 & OAS3 & -2.652 '-5'-oligoadenylate synthetase 3,100 kDa & $(+)$ \\
\hline 5359 & PLSCR1 & -2.65 phospholipid scramblase 1 & $(-)$ \\
\hline 6236 & RRAD & -2.61 Ras-related associated with diabetes & $(-)$ \\
\hline 4496 & MT1H & -2.56 metallothionein $1 \mathrm{H}$ & $(-)$ \\
\hline 4814 & NINJ1 & -2.54 ninjurin 1 & $(+)$ \\
\hline 11309 & SLCO2B1 & -2.5 solute carrier organic anion transporter family, member $2 \mathrm{~B} 1$ & $(+)$ \\
\hline 158158 & RASEF & -2.47 RAS and EF-hand domain containing & $(-)$ \\
\hline 259 & AMBP & $-2.47 \alpha$-1-microglobulin/bikunin precursor & $(-)$ \\
\hline 2669 & GEM & -2.47 GTP binding protein overexpressed in skeletal muscle & $(-)$ \\
\hline
\end{tabular}


Table II. Continued.

\begin{tabular}{|c|c|c|c|}
\hline $\begin{array}{l}\text { Entrez } \\
\text { gene ID }\end{array}$ & Symbol & Average & $\begin{array}{l}\text { Target } \\
\text { site }\end{array}$ \\
\hline 3656 & IRAK2 & -2.42 interleukin- 1 receptor-associated kinase 2 & $(-)$ \\
\hline 3880 & KRT19 & -2.41 keratin 19 & $(-)$ \\
\hline 1978 & EIF4EBP1 & -2.41 eukaryotic translation initiation factor $4 \mathrm{E}$ binding protein 1 & $(+)$ \\
\hline 7431 & VIM & -2.39 vimentin & $(+)$ \\
\hline 57568 & SIPA1L2 & -2.38 signal-induced proliferation-associated 1 like 2 & $(-)$ \\
\hline 7913 & DEK & -2.35 DEK oncogene & $(+)$ \\
\hline 123 & PLIN2 & -2.34 perilipin 2 & $(-)$ \\
\hline 4501 & MT1X & -2.33 metallothionein $1 X$ & $(-)$ \\
\hline 654346 & LGALS9C & -2.31 lectin, galactoside-binding, soluble, $9 \mathrm{C}$ & $(+)$ \\
\hline 4489 & MT1A & -2.3 metallothionein $1 \mathrm{~A}$ & $(-)$ \\
\hline 3669 & ISG20 & -2.28 interferon stimulated exonuclease gene $20 \mathrm{kDa}$ & $(-)$ \\
\hline 2920 & CXCL2 & -2.28 chemokine (C-X-C motif) ligand 2 & $(-)$ \\
\hline 2274 & FHL2 & -2.27 four and a half LIM domains 2 & $(-)$ \\
\hline 157506 & RDH10 & -2.27 retinol dehydrogenase 10 (all-trans) & $(-)$ \\
\hline 25937 & WWTR1 & $-2.26 \mathrm{WW}$ domain containing transcription regulator 1 & $(-)$ \\
\hline 3690 & ITGB3 & -2.26 integrin, $\beta 3$ (platelet glycoprotein IIIa, antigen CD61) & $(+)$ \\
\hline 196513 & DCP1B & -2.24 DCP1 decapping enzyme homolog B (S. cerevisiae $)$ & $(-)$ \\
\hline 9518 & GDF15 & -2.24 growth differentiation factor 15 & $(-)$ \\
\hline 1364 & CLDN4 & -2.23 claudin 4 & $(-)$ \\
\hline 23643 & LY96 & -2.2 lymphocyte antigen 96 & $(-)$ \\
\hline 10561 & IFI44 & interferon-induced protein 44 & $(-)$ \\
\hline 84141 & FAM176A & -2.19 family with sequence similarity 176 , member A & $(-)$ \\
\hline 6281 & S100A10 & -2.17 S100 calcium binding protein A10 & $(-)$ \\
\hline 7088 & TLE1 & -2.17 transducin-like enhancer of split 1 (E(sp1) homolog, Drosophila) & $(-)$ \\
\hline 81553 & FAM49A & -2.17 family with sequence similarity 49, member $\mathrm{A}$ & $(-)$ \\
\hline 4599 & MX1 & $\begin{array}{l}-2.17 \text { myxovirus (influenza virus) resistance } 1 \\
\text { interferon-inducible protein p78 (mouse) }\end{array}$ & $(-)$ \\
\hline 6850 & SYK & -2.17 spleen tyrosine kinase & $(-)$ \\
\hline 7364 & UGT2B7 & -2.17 UDP glucuronosyltransferase 2 family, polypeptide B7 & $(-)$ \\
\hline 5366 & PMAIP1 & -2.17 phorbol-12-myristate-13-acetate-induced protein 1 & $(-)$ \\
\hline 50515 & CHST11 & -2.16 carbohydrate (chondroitin 4) sulfotransferase 11 & $(+)$ \\
\hline 2982 & GUCY1A3 & -2.16 guanylate cyclase 1 , soluble, $\alpha 3$ & $(+)$ \\
\hline 6273 & S100A2 & $-2.15 \mathrm{~S} 100$ calcium binding protein $\mathrm{A} 2$ & $(+)$ \\
\hline 54478 & FAM64A & -2.15 family with sequence similarity 64 , member $A$ & $(-)$ \\
\hline 3428 & IFI16 & -2.14 interferon, $\gamma$-inducible protein 16 & $(-)$ \\
\hline 9615 & GDA & -2.14 guanine deaminase & $(-)$ \\
\hline 7849 & PAX8 & -2.13 paired box 8 & $(-)$ \\
\hline 10550 & ARL6IP5 & -2.11 ADP-ribosylation-like factor 6 interacting protein 5 & $(+)$ \\
\hline 23286 & WWC1 & $-2.1 \quad \mathrm{WW}$ and $\mathrm{C} 2$ domain containing 1 & $(+)$ \\
\hline 9636 & ISG15 & -2.08 ISG15 ubiquitin-like modifier & $(+)$ \\
\hline 896 & CCND3 & -2.07 cyclin D3 & $(+)$ \\
\hline 5329 & PLAUR & -2.07 plasminogen activator, urokinase receptor & $(-)$ \\
\hline 4853 & NOTCH2 & -2.06 Notch homolog 2 (Drosophila) & $(+)$ \\
\hline 55652 & SLC48A1 & -2.05 solute carrier family 48 (heme transporter), member 1 & $(+)$ \\
\hline 23476 & BRD4 & -2.04 bromodomain containing 4 & $(+)$ \\
\hline 2012 & EMP1 & -2.03 epithelial membrane protein 1 & $(+)$ \\
\hline 3429 & IFI27 & -2.02 interferon, $\alpha$-inducible protein 27 & $(-)$ \\
\hline 79710 & MORC4 & -2.01 MORC family CW-type zinc finger 4 & $(-)$ \\
\hline 80820 & EEPD1 & -2.01 endonuclease/exonuclease/phosphatase family domain containing 1 & $(+)$ \\
\hline
\end{tabular}


Table III. Patient characteristics of immunohistochemistry.

No. of patients (\%)

\begin{tabular}{lrr}
\hline Total number & 67 & \\
Age (average) & $30-80$ & $(54.4)$ \\
Gender & & \\
Male & 45 & $(67.2)$ \\
Female & 22 & $(32.8)$ \\
Pathological tumor stage & & \\
pT1 & 15 & $(22.4)$ \\
pT2 & 28 & $(41.8)$ \\
pT3 & 22 & $(32.8)$ \\
pT4 & 2 & $(3.0)$ \\
Grade & & \\
G1 & 52 & $(77.6)$ \\
G2 & 14 & $(20.9)$ \\
G3 & 1 & $(1.5)$ \\
Normal tissue & 10 & \\
\hline
\end{tabular}

dish), 6-well plates for wound healing assays $\left(20 \times 10^{4}\right.$ cells per well), in 24-well plates for the mRNA extraction and Matrigel invasion assays $\left(5 \times 10^{4}\right.$ cells per well) and in 96-well plates for the XTT assays (3,000 cells per well).

Cell morphology. Cells were transfected with $m i R-138$ and si-VIM for $72 \mathrm{~h}$ and were then examined by an inverted microscope (CK2-BIP2, Olympus).

Cell proliferation, migration and invasion assays. Cell proliferation was determined using an XTT assay (Roche Applied Science, Tokyo, Japan) that was performed according to the manufacturer's instructions. Cell migration activity was evaluated with a wound healing assay. Cells were plated in 6-well dishes and the cell monolayer was scraped using a P-20 micropipette tip. The initial gap length $(0 \mathrm{~h})$ and the residual gap length $24 \mathrm{~h}$ after wounding were calculated from photomicrographs. A cell invasion assay was carried out using modified Boyden Chambers consisting of Transwell-precoated Matrigel membrane filter inserts with $8-\mathrm{mm}$ pores in 24-well tissue cultures plates (BD Bioscience, Bedford, MA, USA). Minimum essential medium containing $10 \%$ FBS in the lower chamber served as the chemoattractant as described previously (24). All experiments were performed in triplicate.

Screening of miR-138-regulated genes by microarray. Oligomicroarray Human $60 \mathrm{~K}$ (Agilent) was used for expression signature in miR-138-transfected A498 cells in comparison with the miR-negative control transfectant, as previously described (23). Briefly, hybridization and washing steps were performed in accordance with the manufacturer's instructions. The arrays were scanned using a Packard GSI Lumonics ScanArray 4000 (PerkinElmer, Boston, MA, USA). The data obtained were analyzed with DNASIS array software (Hitachi Software Engineering, Tokyo, Japan) that converted the signal intensity. Data from each microarray study were normalized by global normalization.
Expression signature of RCC clinical specimens by microarray. Oligo-microarray Human 60K (Agilent) was used for expression signature in 5 pairs of RCC clinical specimens compared with adjacent non-cancerous tissues. Their age ranged from 42 to 77 years; 3 were G1 and 2 were G2 in their tumor grading; and all were pT1N0M0 tumors.

Western blot analysis. After three days of transfection, protein lysates $(40 \mu \mathrm{g})$ were separated by NuPAGE on $4-12 \%$ bis-tris gels (Invitrogen) and transferred onto polyvinylidene fluoride membranes. Immunoblotting was done with diluted (1:500) polyclonal VIM antibody (HPA001762; Sigma-Aldrich) and GAPDH antibody (MAB374; Chemicon, Temecula, CA, USA). The membrane was washed and then incubated with goat antirabbit IgG (H+L)-HRP conjugate (Bio-Rad, Hercules, CA, USA). Specific complexes were visualized with an echochemiluminescence (ECL) detection system (GE Healthcare, Little Chalfont, UK), and the expression levels of these genes were evaluated by ImageJ software (ver. 1.43; http://rsbweb.nih.gov/ij/index.html).

Immunohistochemistry. A tissue microarray of 67 RCC samples and 10 normal kidney samples was obtained from US Biomax Inc. (KD806; Rockville, MD, USA). Detailed information on all tumor specimens can be found at http:/www.biomax.us/ index.php. Patient characteristics are summarized in Table III. Immunostaining was done on the tissue microarray following the manufacturer's protocol by UltraVision Detection System (Thermo Scientific). The primary rabbit polyclonal antibodies against VIM (Sigma-Aldrich) were diluted 1:500. The slides were treated with biotinylated goat anti-rabbit. Diaminobenzidine hydrogen peroxidase was the chromogen, and the counterstaining was done with $0.5 \%$ hematoxylin. Immunostaining was evaluated according to a scoring method described previously (14). Each case was scored on the basis of the intensity and area of staining. The intensity of staining was graded on the following scale: 0 , no staining; $1+$, mild staining; $2+, 30-60 \%$ stained positive; $3+,>60 \%$ stained positive. A combined staining score (intensity + extent) of $<2$ was low expression, a score between 3 and 4 was moderate expression, and a score between 5 and 6 was high expression.

Statistical analysis. The relationships between two variables and numerical values were analyzed using the Mann-Whitney $\mathrm{U}$ test, and the relationship between three variables and the numerical values was analyzed using the Bonferroni-adjusted Mann-Whitney U test. Expert Stat View analysis software (ver. 4; SAS institute Inc., Cary, NC, USA) was used in both analyses. In the comparison of three variables, a non-adjusted statistical level of significance of $\mathrm{P}<0.05$ corresponded to the Bonferroni-adjusted level of $\mathrm{P}<0.0167$.

\section{Results}

Effect of miR-138 transfection on cell proliferation, migration, and invasion activity of RCC cell lines. In this study, we firstly observed that restoration of $m i R-138$ in RCC cell lines (A498 and 786-O) changed the bleb-like cell morphology characteristic of the epithelial-mesenchymal transition (EMT) (Fig. 1A). A morphological change of cancer cells by miRNA transfection is an important discovery and it suggested that $m i R-138$ functions 
A

\section{A498}

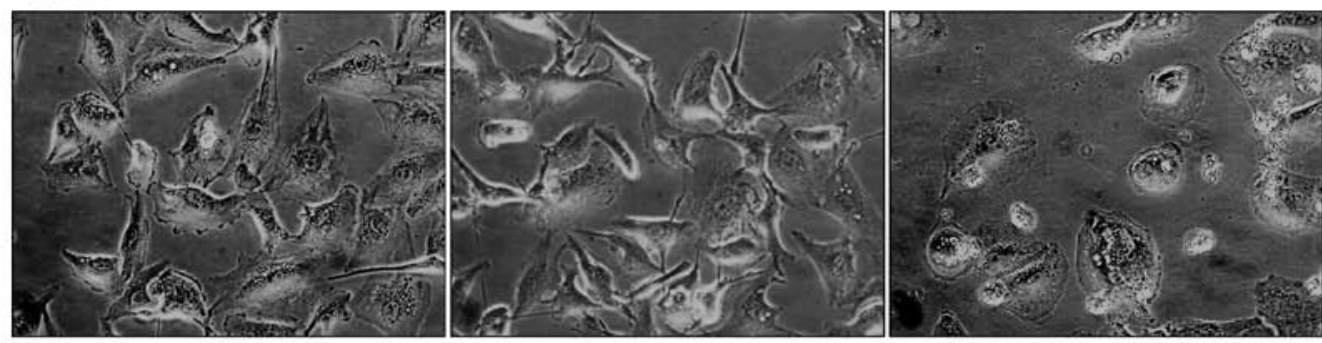

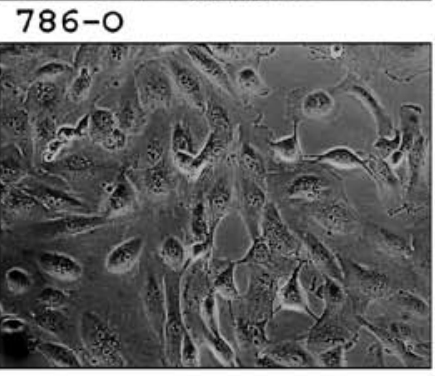

mock

B

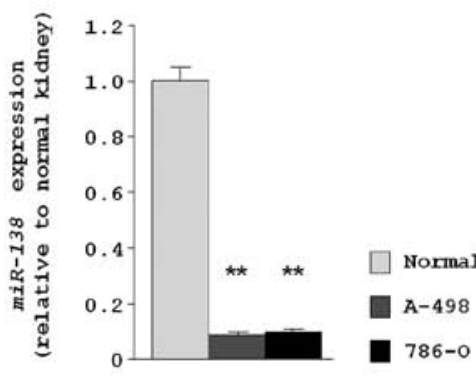

D
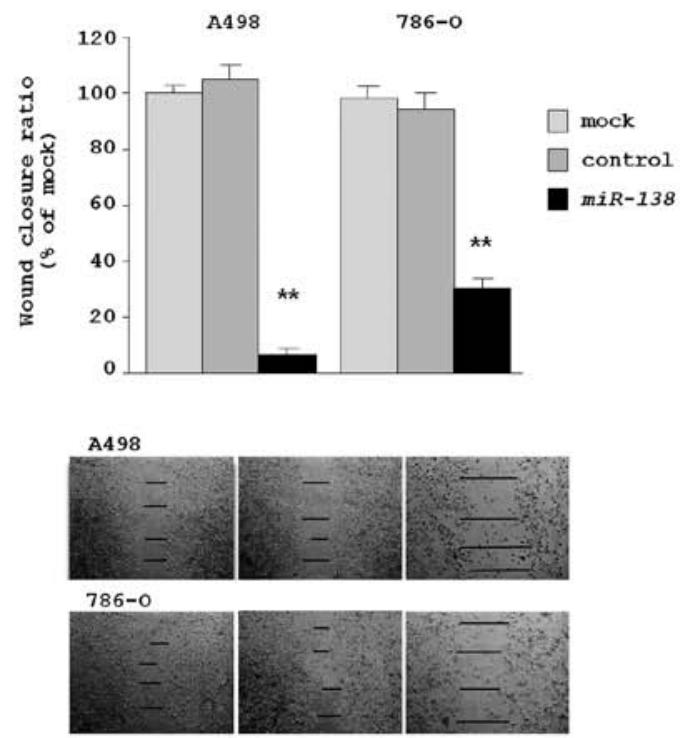

mock

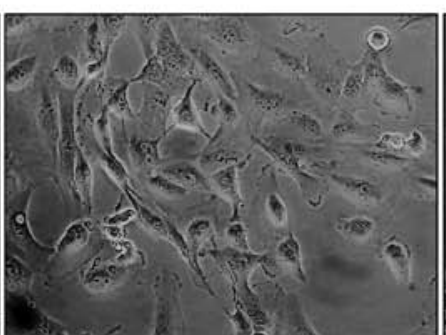

control

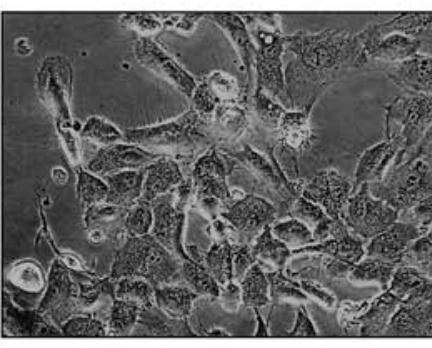

miR-138

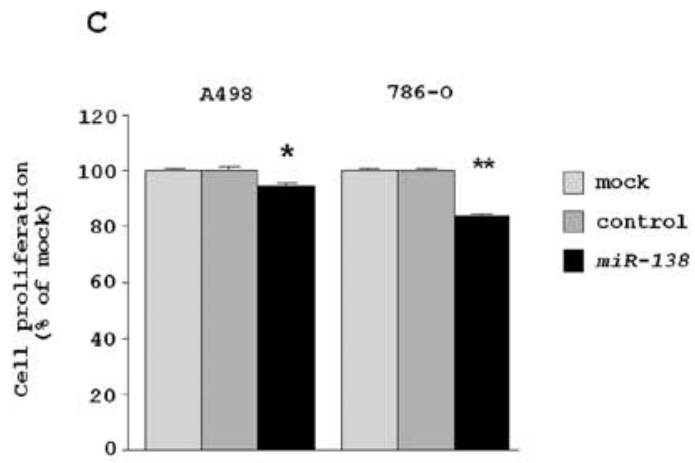

$\mathbf{E}$
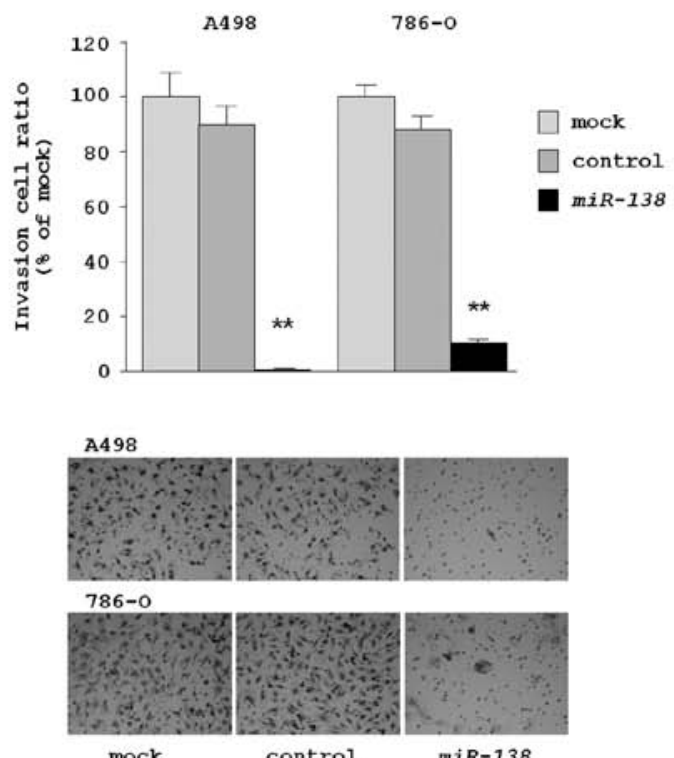

mock

$\operatorname{miR}-138$

Figure 1. Effect of miR-138 transfection on RCC cell lines. (A) The change of morphology of miR-138 transfectants. A498 and 786-O cells were transfected with $m i R-138$ for $72 \mathrm{~h}$ and were then examined by an inverted microscope. (B) miR-138 expression in A498 and 786-O cell lines and in normal kidney. miR-138 expression levels in A498 and 786-O were significantly lower than those in normal human kidney RNA. RNU6B was used as an internal control. (C-E) Effect of $m i R-138$ transfection of A498 and 786-O cells. (C) Cell proliferation determined by the XTT assay; (D) cell migration activity determined by wound healing assay; and $(\mathrm{E})$ cell invasion activity determined by the Matrigel invasion assay. ${ }^{*} \mathrm{P}<0.001,{ }^{* *} \mathrm{P}<0.0001$. 
A

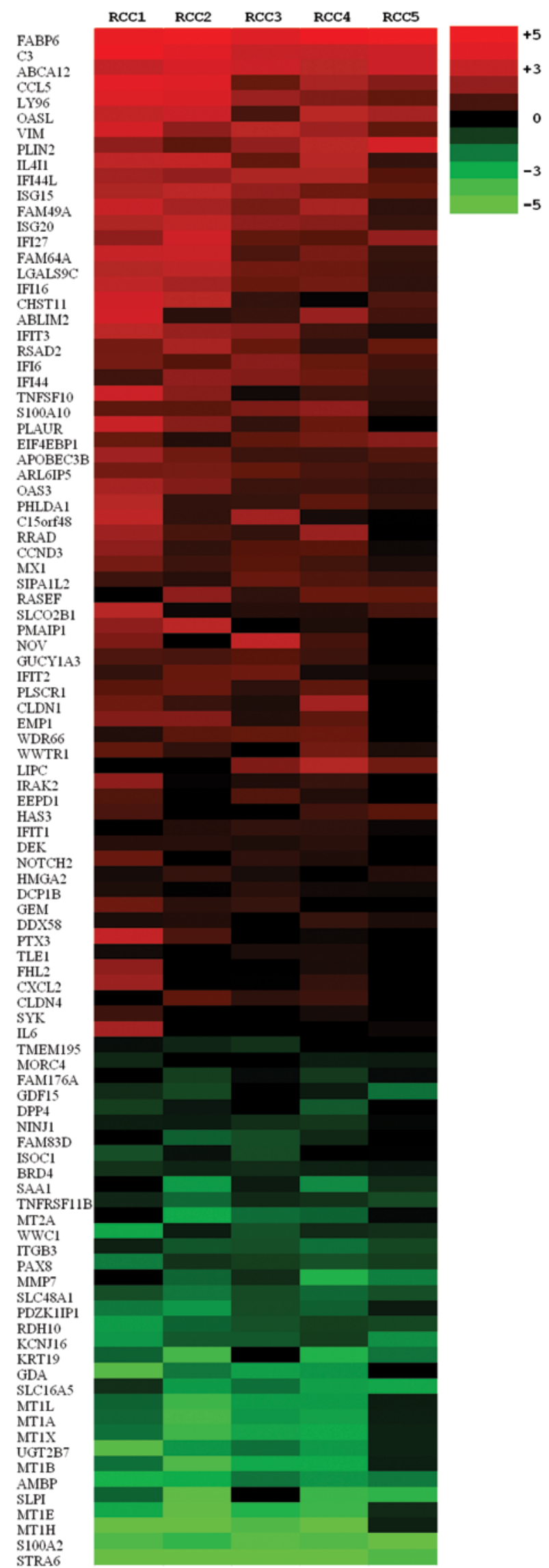

B

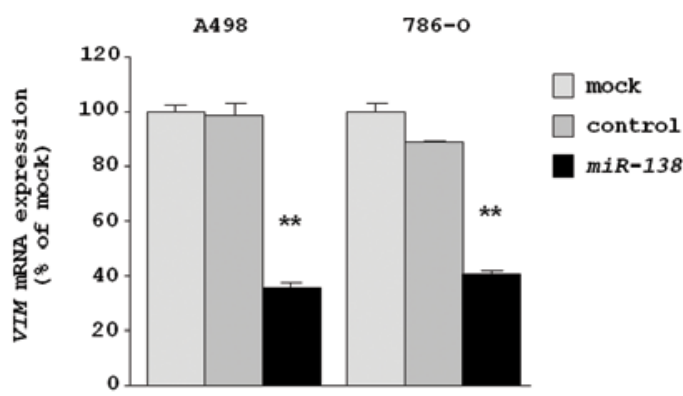

C

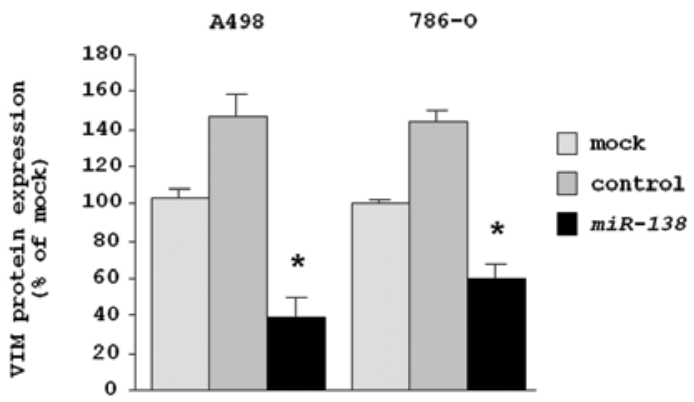

vIM

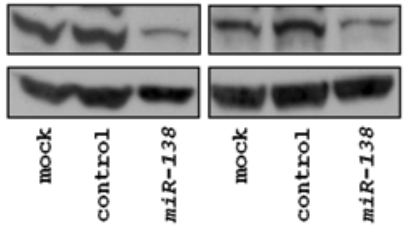

D

Human VIM (MM_003380) 3'UTR length:322

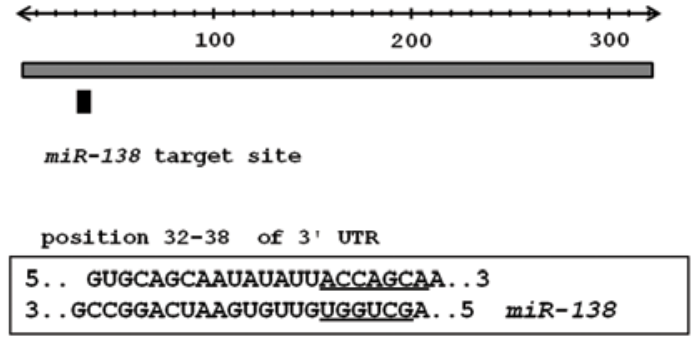

Figure 2. miR-138 regulates molecular targets in RCC cells. (A) Heatmap derived from five RCC samples. A total of 99 genes were downregulated less than -2.0-fold in miR-138 transfectants. We checked their mRNA expression levels in RCC by using our previous gene expression analysis of five RCC specimens. Ninety-nine gene expression levels are shown in the heat map diagram. VIM was the top upregulated gene among the genes which have miR-138 target sites in the heat map diagram. (B) VIM mRNA expression after $24 \mathrm{~h}$ transfection with $10 \mathrm{nM}$ miR-138. (C) VIM protein expression after $72 \mathrm{~h}$ transfection of miRNAs. GAPDH was used as a loading control. The mRNA and protein levels of VIM were repressed in the transfectants. ${ }^{*} \mathrm{P}<0.01,{ }^{* *} \mathrm{P}<0.0001$, (D) miR-138 binding sites in the 3 'UTR of VIM mRNA. 
A

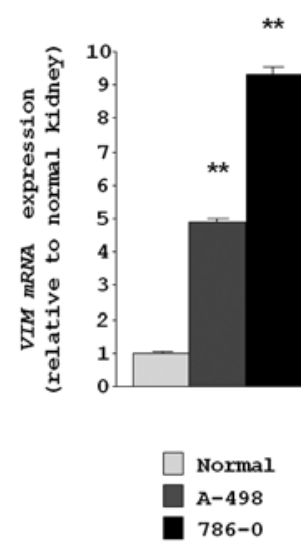

B

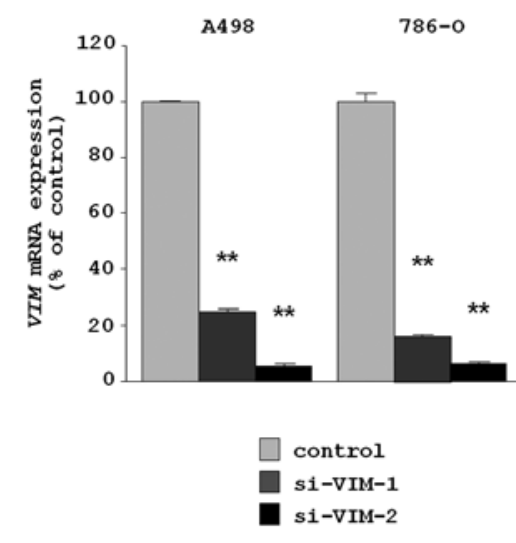

C

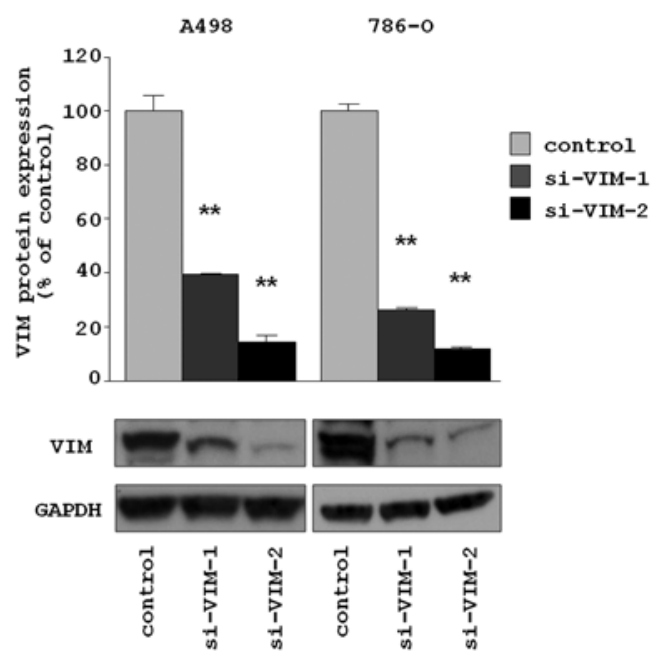

Figure 3. VIM expression was suppressed by si-VIM transfection on RCC cell lines. (A) The expression of VIM mRNAs in A 498 and $786-0$ cell lines and normal kidney. The mRNA expression levels of VIM were 4- and 9-fold higher in RCC cell lines compared to the normal kidney RNA. GUSB was used as an internal control. (B) VIM mRNA expression after $24 \mathrm{~h}$ of transfection with $10 \mathrm{nM}$ si-VIM. VIM mRNA expression was repressed in si-VIM transfectants. GUSB was used as an internal control. (C) VIM protein expression after $72 \mathrm{~h}$ transfection of si-VIM. GAPDH was used as a loading control. The expression level of VIM was also repressed in the transfectants.

as a tumor suppressor in RCC cells. To explore that possibility, the following experiments were conducted.

We evaluated the expression levels of $m i R-138$ in two RCC cell lines, A498 and 786-O. RNA was extracted and miRNA expression levels of $m i R-138$ were determined by real-time RT-PCR. The expression levels of $m i R-138$ were significantly lower in both RCC cell lines compared with normal kidney RNA (relative to normal kidney RNA, $0.090 \pm 0.008$ and $0.102 \pm 0.009$, respectively) (Fig. 1B).

The XTT assay revealed that cell proliferation was significantly inhibited in $m i R-138$ transfectants in comparison with the transfectant reagent only (mock) and the miR-control transfectants. The percentages of cell proliferation for A498 were $94.6 \pm 0.9,100.0 \pm 0.8$ and $100.0 \pm 1.0$, respectively, each $\mathrm{P}=0.0008$. For $786-\mathrm{O}$, the percentages were $83.5 \pm 1.1,100.0 \pm 0.4$ and 100.3 \pm 0.6 , respectively, $\mathrm{P}<0.0001$ (Fig. 1C).

The wound healing assay demonstrated that significant inhibition of cell migration occurred in the miR-138 transfectants in comparison with mock and the miR-control transfectants. The percentages of wound closure for A498 were 6.5 $\pm 2.3,100.0 \pm 2.7$ and $104.8 \pm 4.9$, respectively, each $\mathrm{P}<0.0001$. For $786-\mathrm{O}$, the percentages were $30.7 \pm 3.8,100.0 \pm 4.4$ and $95.9 \pm 5.4$, respectively, each $\mathrm{P}<0.0001$ (Fig. 1D).

The Matrigel invasion assay demonstrated that the number of invading cells significantly decreased in the $m i R$-138-transfectants in comparison with mock and the miR-control transfectants. The percentages of cell invasion for A498 were $0.9 \pm 0.4,100.0 \pm 8.6$ and 83.1 \pm 7.4 , respectively, each $\mathrm{P}<0.0001$. For 786-O, the values were $10.9 \pm 1.1,100.0 \pm 4.4$ and $75.3 \pm 6.2$, respectively, each $\mathrm{P}<0.0001$ (Fig. 1E).

miR-138 regulation of molecular targets assessed by genomewide gene expression analysis. To confirm that $m i R-138$ regulated molecular targets in RCC cells, we performed genome-wide gene expression analysis using $m i R-138$ trans- fectants compared with miRNA-control transfectants in A498 cells. A total of 99 genes were downregulated in $m i R$ - 138 transfectants. Among them, 24 genes had putative target site(s) in their 3' untranslated region (3'UTR) according to the TargetScan miRNA program (Table II).

Furthermore, we performed gene expression analysis using RCC clinical specimens (5 pairs of RCC and adjacent non-cancerous tissues). Several protein-coding genes were differentially expressed in this signature (data not shown). We selected 99 genes that were downregulated in $m i R-138$ transfectants and demonstrated their expression levels in a heatmap diagram (Fig. 2A). Entries from the microarray data were approved by the Gene Expression Omnibus (GEO), and were assigned GEO accession numbers GSE 36951 (RCC clinical specimens) and GSE 37119 (miR-138 transfectants).

The two expression signatures in this study ( $m i R-138$ transfectants and RCC clinical specimens) revealed that VIM was a promising putative target gene in $m i R-138$ in RCC. Thus, we focused on the VIM gene and investigated the functional significance of VIM in RCC cells.

VIM as a direct target of repression by miR-138 in RCC cells. The mRNA and protein expression levels of VIM were markedly downregulated in $m i R-138$ transfectants (A498 and 768-O) in comparison with the mock and miRNA-control transfectants (Fig. 2B and C). The predicted target site of $m i R-138$ in VIM in the 3'UTR is shown in Fig. 2D.

Silencing of VIM in RCC cell lines and the effect on cell proliferation, migration and invasion. First, we assessed the expression level of VIM in cells to be used for functional analysis of VIM. VIM mRNA expression levels in A498 and 786-O were significantly higher than those in normal human kidney RNA (relative to normal kidney RNA, 4.879 \pm 0.131 and 9.298 \pm 0.255 , respectively, each $\mathrm{P}<0.0001$ ) (Fig. 3A). 
A

A498

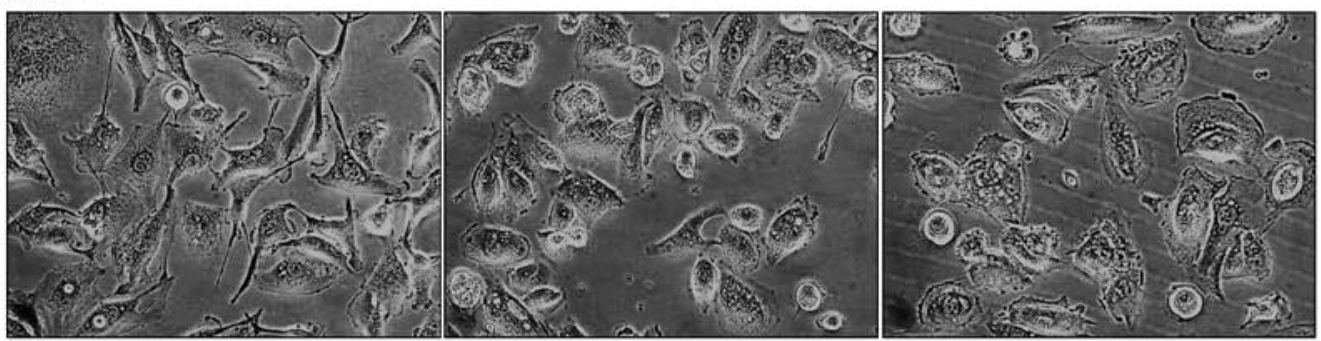

786-0

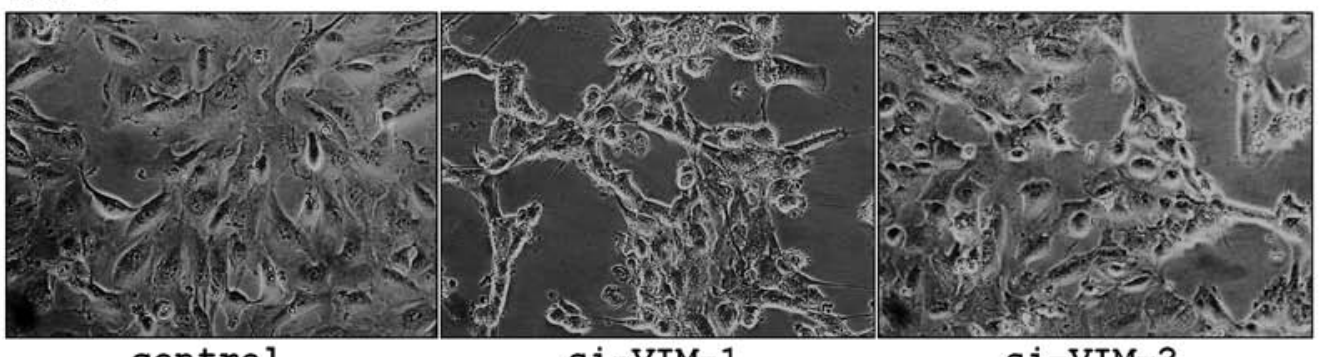

control

si-VIM-1

si-VIM-2

B

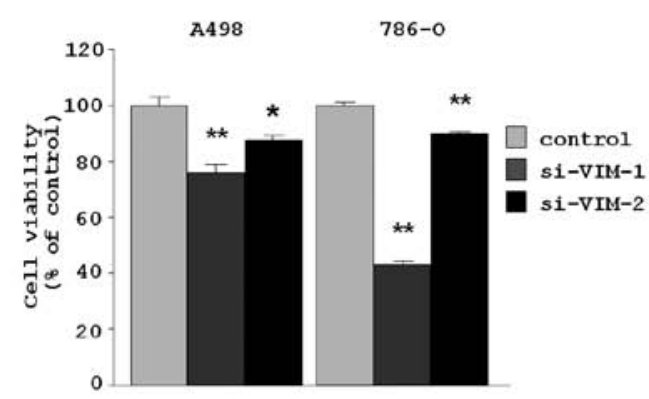

C

D
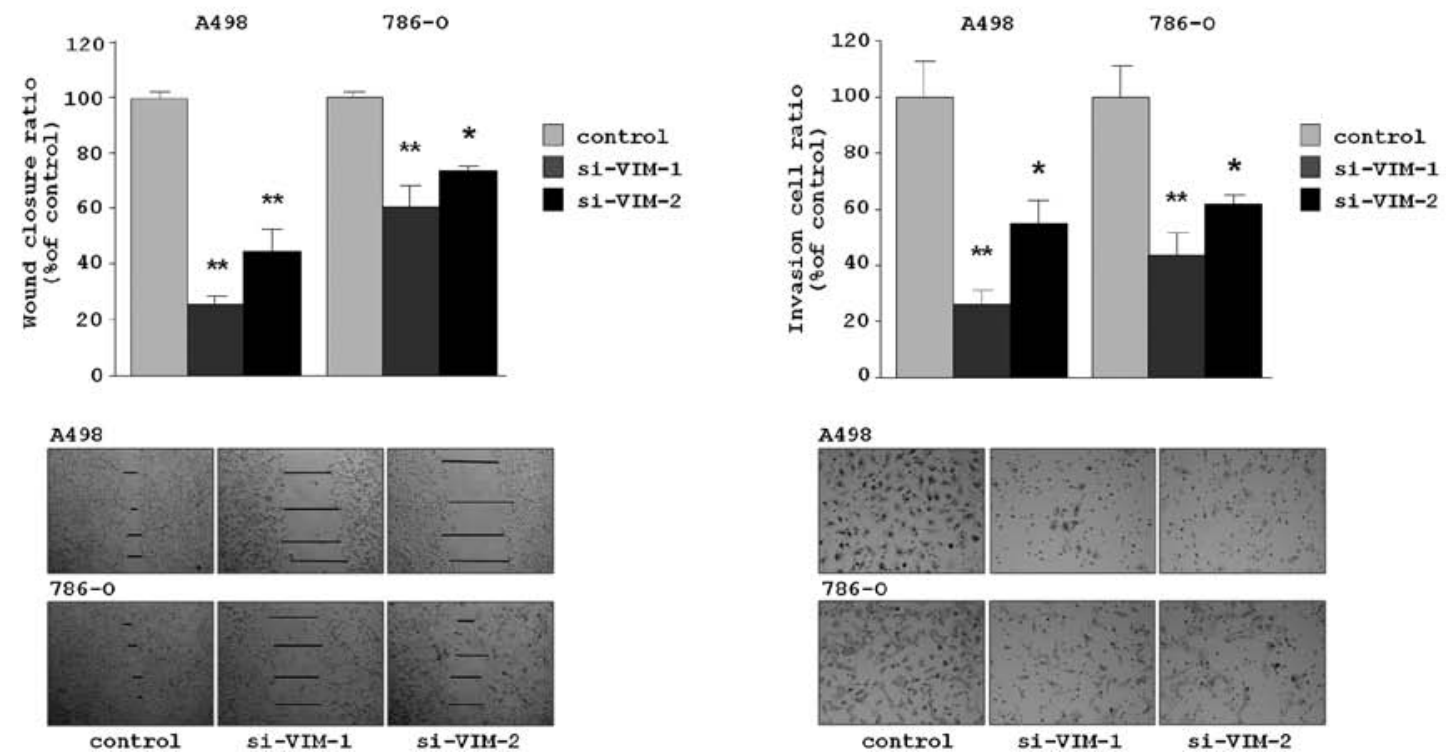

Figure 4. Response to VIM silencing by si-VIM transfection of RCC cell lines. (A) The change of morphology of si-VIM transfectants. A498 and 786-O cells were transfected with si-VIM for $72 \mathrm{~h}$ and were then examined by an inverted microscope. (B-D) VIM-knockdown effects on A498 and 786-0 cell lines transfected with si-VIM-1 and si-VIM-2. (B) Cell proliferation determined by the XTT assay; (C) cell migration activity determined by the wound healing assay; and (D) cell invasion activity determined by the Matrigel invasion assay. ${ }^{*} \mathrm{P}<0.005,{ }^{* *} \mathrm{P}<0.0001$. 
A

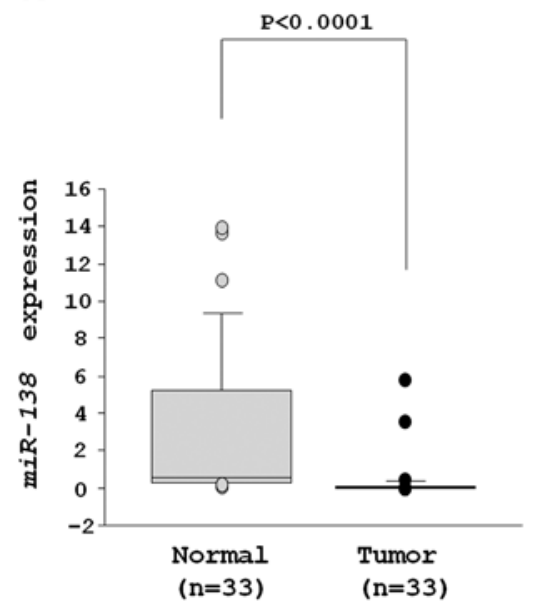

B

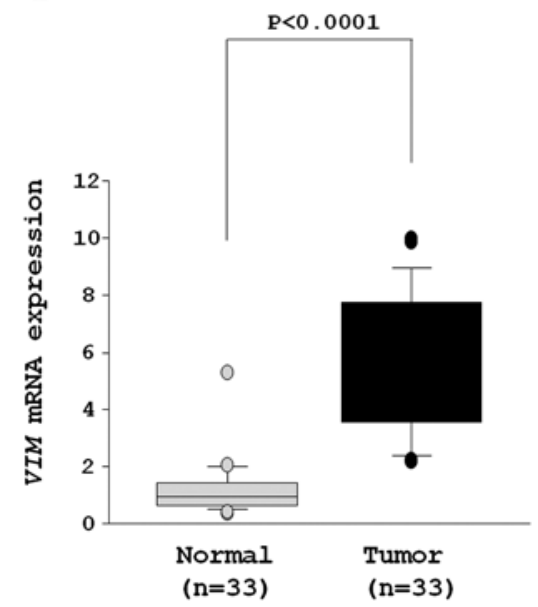

C

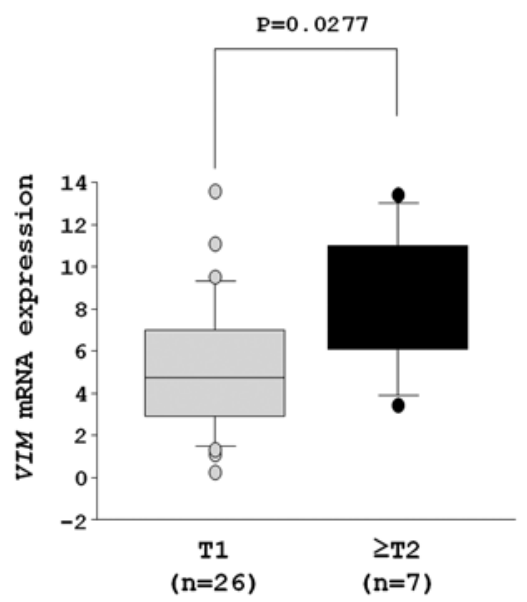

Figure 5. The expression levels of $m i R-138$ and VIM in RCC clinical specimens. (A and B) miR-138 and VIM mRNA expression levels of 33 RCC and adjacent non-cancerous kidney tissues. Relative expression levels are expressed in box plots. (A) Expression levels of miR-138 in RCC clinical samples were significantly downregulated compared with adjacent normal kidney. (B) Expression levels of VIM mRNA in RCC clinical samples were significantly upregulated compared with adjacent normal kidney samples. (C) The correlation of VIM mRNA between $\mathrm{T} 1$ and $\geq \mathrm{T} 2$ in RCC samples. VIM expression in $\geq \mathrm{T} 2$ RCC samples was significantly higher compared with T1 RCC samples.

To examine the functional role of VIM, we performed loss-of-function studies using two different siRNAs, si-VIM- 1 and si-VIM-2 transfected into A498 and 768-O cell lines. The mRNA and protein expression levels of VIM were markedly downregulated in both si-VIM-1 and si-VIM-2 transfectants (A498 and 768-O) in comparison with the siRNA-control transfectants (Fig. 3B and C). This result shows that two siRNA were useful for loss-of-function assays in this study.

Transfection of si-VIM-1 and si-VIM-2 in the RCC cell lines (A498 and 768-O) caused EMT-like changes in cell morphology, as that observed when cells were transfected with $m i R-138$ (Fig. 4A).

The XTT assay revealed that cell proliferation was inhibited in both si-VIM-transfectants in comparison with the si-control transfectants. The percentages of cell proliferation for A498 were $76.1 \pm 2.6,87.5 \pm 1.9$ and $100.0 \pm 3.1$, respectively, $\mathrm{P}<0.0001$ and $\mathrm{P}=0.0038$. For $786-\mathrm{O}$, the values were $43.1 \pm 1.0,89.9 \pm 0.7$ and $100.0 \pm 1.1$, respectively, $\mathrm{P}<0.0001$ (Fig. 4B).

The wound healing assay demonstrated that significant inhibition of cell migration occurred in the si-VIM-transfectants in comparison with the si-control transfectants. The percentages of wound closure for A498 were 26.0 $10.6,44.7 \pm 8.4$ and $100.0 \pm 2.6$, respectively, each $\mathrm{P}<0.0001$. For $786-\mathrm{O}$, the values were $60.8 \pm 7.3,73.0 \pm 1.7$ and $100.0 \pm 7.1$, respectively, $\mathrm{P}<0.0001$ and $\mathrm{P}=0.0002$ (Fig. 4C).

The Matrigel invasion assay demonstrated that the number of invading cells significantly decreased in the si-VIM-transfectants in comparison with the si-control transfectants. For A498, the percentages of cells invading were $26.5 \pm 4.7,54.8 \pm 8.3$ and $100.0 \pm 12.4$, respectively, $\mathrm{P}<0.0001$ and $\mathrm{P}=0.0019$. For $786-\mathrm{O}$, the values were $43.6 \pm 8.3,61.6 \pm 3.3$ and $100.0 \pm 11.1$, respectively, $\mathrm{P}<0.0001$ and $\mathrm{P}=0.0034$ (Fig. 4D).

Expression levels of miR-138 and VIM mRNA in RCC clinical specimens. Quantitative stem-loop RT-PCR demonstrated that the expression levels of $m i R-138$ were significantly reduced in 33 RCC samples (Table I) in comparison with adjacent non- cancerous specimens (clinical RCC specimens, $0.346 \pm 0.201$ versus adjacent normal tissues, $2.983 \pm 0.715, \mathrm{P}<0.0001$ ) (Fig. 5A).

On the other hand, the mRNA expression level of VIM was significantly higher in RCC than adjacent non-cancerous specimens (clinical RCC specimens, $6.017 \pm 0.622$, adjacent normal tissues; $1.316 \pm 0.224, \mathrm{P}<0.0001$ ) (Fig. 5B).

The mRNA expression of $\geq T 2$ specimens $(n=7)$ was significantly higher than that of $\mathrm{T} 1(\mathrm{n}=26)(\mathrm{T} 1,5.230 \pm 0.607 ; \geq \mathrm{T} 2$, $8.773 \pm 1.349$, $\mathrm{P}=0.0277$ ) (Fig. 5C).

Immunohistochemistry of VIM in tissue microarray. VIM was detected by immunohistochemical staining. Fig. 6A-D shows representative results of immunohistochemical staining of VIM. VIM was strongly expressed in tumor lesions (Fig. 6A-C), whereas no expression was observed in normal tissue (Fig. 6D). The expression score of VIM was significantly higher in 67 RCC specimens in comparison with ten normal kidney specimens (Fig. 6E). The VIM expression of $\geq T 2$ specimens $(n=52)$ was higher than that of $\mathrm{T} 1(\mathrm{n}=15)$. There was a trend but no significant difference in the expression score of VIM between $\mathrm{T} 1$ and $\geq \mathrm{T} 2$ specimens $(\mathrm{P}=0.053$, Fig. $6 \mathrm{~F})$. While there was a trend between VIM expression and grade, the difference was not significant. Patient characteristics are summarized in Table III.

\section{Discussion}

The incidence of RCC has increased over the last few decades, and it currently represents approximately $2 \%$ of all cancer-related deaths (25). Although two-thirds of RCC patients have clinically localized disease and will undergo curative surgery, up to $40 \%$ of patients develop distant metastasis and their outcomes are poor (2-4). Many studies have indicated that cell adhesion and extra-cellular matrix proteins contribute to the cells' acquired abilities for invasion, migration and metastasis (26).

EMT is an embryologically conserved genetic program that is an essential step enabling cancer cell invasion and metastasis. For example, epithelial cells lose intercellular 
A

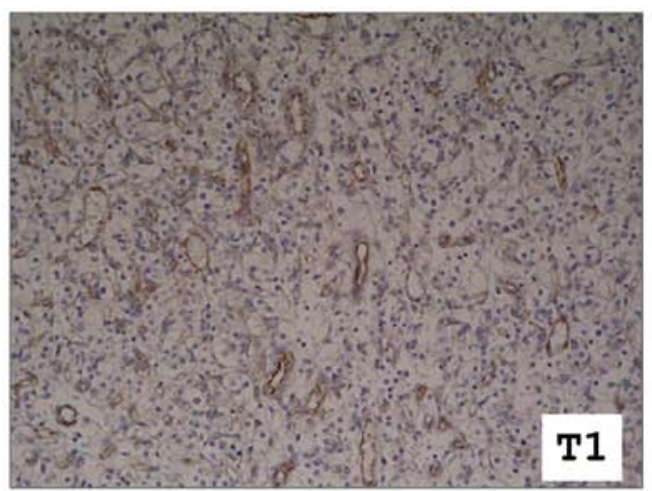

C

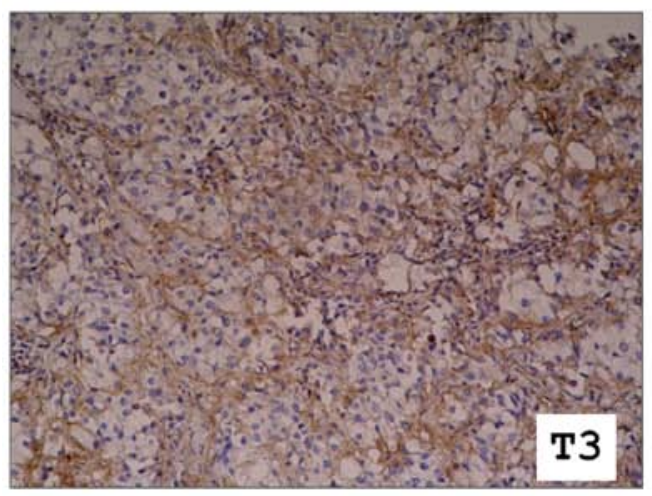

E

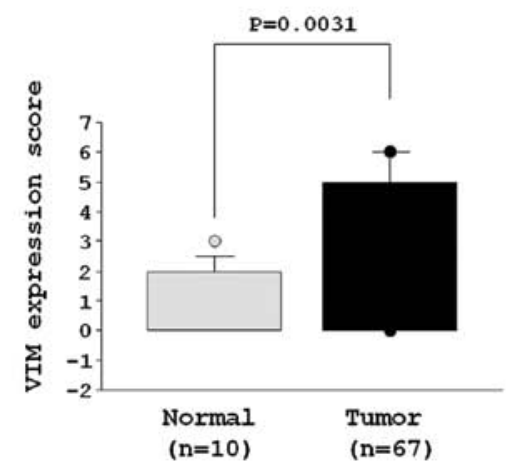

B

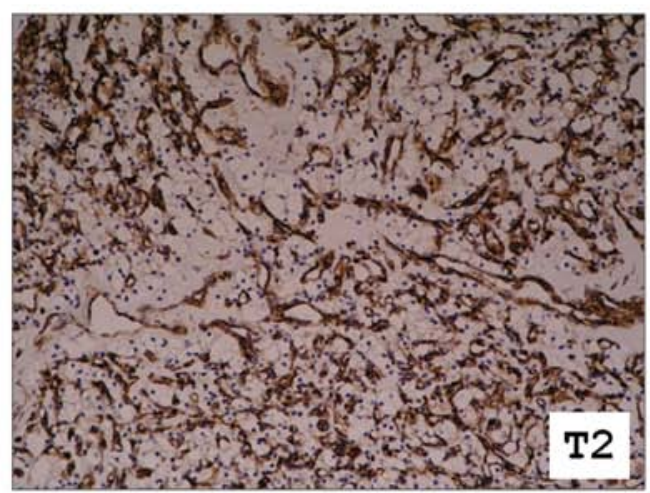

D

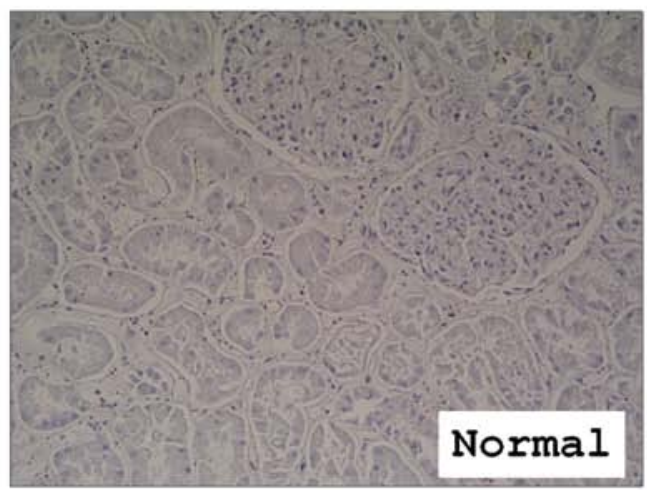

F

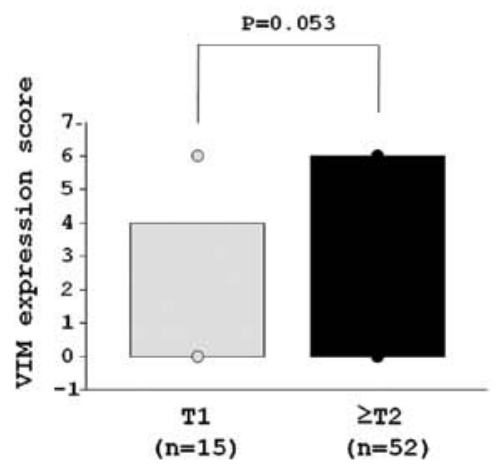

Figure 6. Immunohistochemical staining of VIM in tissue microarray. (A-C) Positively stained tumor lesions (A) T1 N0 M0; (B) T2 N0 M0 and (C) T3 N0 M0. (D) Negative staining in normal kidney tissue. (E-F) VIM expression levels in immunohistochemical staining; (E) VIM expression in normal kidney and RCC; (F) correlation between VIM expression and clinic pathologic parameters in RCC.

tight junctions and polarity (27). Recent data indicate that the microRNA-200 family ( $m i R-200 a,-200 b,-200 c,-141$ and -429) is downregulated in aggressive human cancers. Moreover, it plays critical roles in the inhibition of key regulators of EMT and $\beta$-catenin/Wnt signaling $(28,29)$. Interestingly, our miRNA expression signature of RCC showed that all $m i R$-200 family members were reduced in clinical specimens and that restoration of the $m i R-200$ family inhibited cancer cell migration and invasion (data not shown).

Our previous study showed that $m i R-138$ was reduced in RCC miRNA expression signature (12), we validated the downregulation of $m i R-138$ in RCC clinical specimens in this study.
Aberrant expression of $m i R-138$ has been observed in several types of cancer such as head and neck squamous cell carcinoma (HNSCC) (30), anaplastic thyroid carcinoma (19) and lung cancer (20). Two $m i R-138$ precursor genes, $m i R-138-1$ and $m i R-138-2$, have identical sequences in the mature miRNA and map to human chromosomes 3p21.33 and 16q13, respectively. Although it is believed that genomic deletion or epigenetic silencing of miRNA in cancer cells, the molecular mechanism of downregulated miRNAs in RCC is not clear. In the human chromosomal region $3 \mathrm{p}, \mathrm{LOH}$ is frequently observed in many cancers including RCC $(31,32)$. This problem can be solved by genome-based high throughput analysis in each clinical case. 
Importantly, we found significant morphologic change in RCC cell lines (A498 and 786-O) by $m i R-138$ transfection. Furthermore, restoration of $m i R-138$ significantly inhibited cancer cell migration and invasion in RCC cells. These data suggested that $m i R-138$ functions as a tumor suppressor that inhibits RCC invasion and metastasis. miRNAs are unique in their ability to regulate many protein-coding genes. A single miRNA is capable of targeting a number of genes to regulate biological processes globally. Bioinformatic predictions suggest that miRNAs regulate more than $30 \%$ of protein coding genes (9). The elucidation of new molecular pathways regulated by tumor suppressive $m i R-138$ is important for our understanding of human RCC invasion and metastasis. Based on this view, we performed molecular target searches for $m i R-138$ in cancer cells by combining two genome-wide gene expression studies (miR-138 transfectants and RCC mRNA clinical signature) and in silico analysis.

In this study, we focused on VIM as a putative candidate of $m i R-138$ in RCC cells. We chose VIM for the following reasons. First, downregulation of VIM was recognized in the expression signature of $m i R-138$ transfectants. Second, overexpression of VIM was observed in RCC clinical specimens. Third, VIM has a putative $m i R-138$ target site in its $3^{\prime}$ untranslated region. Our data demonstrated that restoration of $m i R-138$ significantly inhibited both $\mathrm{mRNA}$ and protein expression levels of VIM in RCC cells, suggesting VIM was regulated by tumor suppressive $m i R-138$. It is well known that VIM is an essential constituent of cytoskeletal proteins of mesenchymal cells and VIM is a marker of EMT (21). During EMT, cytoskeletal proteins are changed from keratin-rich networks to VIM-rich networks connected to focal adhesions. Morphological changes of RCC cells and accelerated cell migration and invasion is caused by the reduction of $m i R-138$ and the upregulation of VIM pathways. Interestingly, it has been shown that $m i R-138$ regulated cell migration and invasion by targeting $R h o C, R O C K, Z E B 2, E Z H 2$ and $V I M$ in HNSCC cells $(33,34)$. Importantly, restoration of $m i R-138$ in an HNSCC cell line changed the EMT-like cell morphology and suppressed cell migration and invasion (34). This result is in accord with the data obtained in our study of RCC. Furthermore, overexpression of $m i R-138$ reduced cell viability and colony formation in HCC cell lines targeting CCND3 (35). The report also showed that protein expression of CCND3 was negatively correlated with $m i R-138$ expression in HCC tissues. Our data of miR-138 transfectants in $\mathrm{RCC}$ cell lines demonstrated that $C C N D 3$ is a putative target of $m i R-138$ in RCC, suggesting that $m i R-138$ regulation of the $C C N D 3$ pathway is important for RCC oncogenesis.

The results of this study and previous data indicate that $V I M$ is a functional target of tumor suppressive $m i R-138$, and this pathway contributes to cancer cell migration, invasion, and metastasis. In this study, we also demonstrated overexpression of VIM in clinical specimens of RCC. Previous studies indicated that VIM was a sensitive and specific marker for conventional RCCs $(36,37)$. The combination of VIM and CD9 staining was found to distinguish clear cell RCC and chromophobe RCC (37). Our tissue microarray data showed a positive correlation between VIM expression and tumor grade in RCC specimens. In this analysis, we were not able to obtain a correlation of VIM expression and metastasis in
RCC patients. Silencing of VIM in RCC cell lines changed cell morphology and significantly inhibited cell migration and invasion in this study. Thus, we propose that overexpression of VIM participates in metastasis of RCC. Studies of a large number of samples with balanced pathological backgrounds are needed to elucidate the precise correlation between VIM and/or $m i R-138$ expression and clinicopathological parameters.

In summary, the reduction of $m i R-138$ and the increased expression of VIM are frequent events in RCC clinical specimens. Restoration of $m i R-138$ in RCC cells changed the EMT-like morphology and suppressed cell migration and invasion. The tumor suppressive $m i R-138$-mediated cancer pathway provides new insights into the potential mechanisms of RCC oncogenesis and metastasis.

\section{Acknowledgements}

This research was supported by the Ministry of Education, Science, Sports and Culture Grant-in-Aid for Scientific Research (C), 20591861 and 21592187.

\section{References}

1. Karumanchi SA, Merchan J and Sukhatme VP: Renal cancer: molecular mechanisms and newer therapeutic options. Curr Opin Nephrol Hypertens 11: 37-42, 2002.

2. Janzen NK, Kim HL, Figlin RA and Belldegrun AS: Surveillance after radical or partial nephrectomy for localized renal cell carcinoma and management of recurrent disease. Urol Clin North Am 30: 843-852, 2003.

3. Koul H, Huh JS, Rove KO, Crompton L, Koul S, Meacham RB and Kim FJ: Molecular aspects of renal cell carcinoma: a review. Am J Cancer Res 1: 240-254, 2011.

4. Hadoux J, Vignot S and De La Motte Rouge T: Renal cell carcinoma: focus on safety and efficacy of temsirolimus. Clin Med Insights Oncol 4: 143-154, 2010.

5. Huang Y, Dai Y, Yang J, Chen T, Yin Y, Tang M, Hu C and Zhang L: Microarray analisis of microRNA expression in renal cell carcinoma. Eur J Surg Oncol 35: 1119-1123, 2009.

6. Motzer RJ, Bander NH and Nanus DM: Renal-cell carcinoma. N Engl J Med 335: 865-875, 1996.

7. Motzer RJ, Aqarwal N, Beard C, Bhayani S, Bolger GB, Carducci MA, Chang SS, Choueiri TK, Hancock SL, Hudes GR, Jonasch E, Josephson D, Kuzel TM, Lavine EG, Lin DW, Margolin KA, Michaelson MD, Olencki T, Pili R, Ratliff TW, Redman BG, Robertson CN, Ryan CJ, Sheinfeld J, Spiess PE, Wang J and Wilder RB: Kidney cancer. J Natl Compr Canc Netw 9: 960-977, 2011.

8. Agarwala SS and Case S: Everolimus (RAD001) in the treatment of advanced renal cell carcinoma: a review. Oncologist 15: 236-245, 2010.

9. Fillipowicz W, Bhattacharyya SN and Sonenberg N: Mechanisms of post-transcriptional regulation by microRNAs: are the answers in sight? Nat Rev Genet 9: 102-114, 2008.

10. Nelson KM and Weiss GJ: MicroRNAs and cancer: past, present, and potential future. Mol Cancer Ther 7: 3655-3660, 2008.

11. Esquela-Kerscher A and Slack FJ: OncomiRs-microRNAs with a role in cancer. Nat Rev Cancer 6: 259-269, 2006.

12. Hidaka H, Seki N, Yoshino H, Yamasaki T, Yamada Y, Nohata N, Fuse M, Nakagawa $M$ and Enokida H: Tumor suppressive microRNA-1285 regulates novel molecular targets: Aberrant expression and functional significance in renal cell carcinoma. Oncotarget 3: 44-57, 2012.

13. Chiyomaru T, Enokida H, Tatarano S, Kawahara K, Uchida Y, Nishiyama K, Fujimura L, Kikkawa N, Seki N and Nakagawa M: miR-145 and miR-133a function as tumour suppressors and directly regulate FSCN1 expression in bladder cancer. Br J Cancer 102: 883-891, 2010.

14. Yoshino H, Chiyomaru T, Enokida H, Kawakami K, Tatarano S, Nishiyama K, Nohata N, Seki N and Nakagawa M: The tumoursuppressive function of miR-1 and miR-133a targeting TAGLN2 in bladder cancer. Br J Cancer 104: 808-818, 2011. 
15. Kojima S, Chiyomaru T, Kawakami K, Yoshino H, Enokida H, Nohata N, Fuse M, Ichikawa T, Naya Y, Nakagawa M and Seki N: Tumour suppressors miR-1 and miR-133a target the oncogenic function of purine nucleoside phosphorylase (PNP) in prostate cancer. Br J Cancer 106: 405-413, 2012.

16. Nohata N, Hanazawa T, Kikkawa N, Sakurai D, Fujimura L, Chiyomaru T, Kawakami K, Yoshino H, Enokida $\mathrm{H}$ Nakagawa M, Katayama A, Harabuchi Y, Okamoto T and Seki N: Tumor suppressive microRNA-874 regulates novel cancer networks in maxillary sinus squamous cell carcinoma. Br J Cancer 105: 833-841, 2011.

17. Kikkawa N, Hanazawa T, Fujimura L, Nohata N, Suzuki H, Chazono H, Sakurai D, Horiguchi S, Okamoto Y and Seki N: miR-489 is a tumour-suppressive miRNA target PTPN11 in hypopharyngeal squamous cell carcinoma (HSCC). Br J Cancer 103: 877-884, 2010

18. Yamasaki T, Yoshino H, Enokida H, Hidaka H, Chiyomaru T, Nohata N, Kinoshita T, Fuse M, Seki N and Nakagawa M: Novel molecular targets regulated by tumor suppressors microRNA-1 and microRNA-133a in bladder cancer. Int J Oncol 40: 1821-1830, 2012.

19. Mitomo S, Maesawa C, Ogasawara S, Iwaya T, Shibazaki M, Yashima-Abo A, Kotani K, Oikawa H, Sakurai E, Izutsu N, Kato K, Komatsu H, Ikeda K, Wakabayashi G and Masuda T: Downregulation of miR-138 is associated with overexpression of human telomerase reverse transcriptase protein in human anaplastic thyroid carcinoma cell lines. Cancer Sci 99: 280-286, 2008.

20. Seike M, Goto A, Okano T, Bowman ED, Schetter AJ, Horikawa I, Mathe EA, Jen J, Yang P, Sugimura H, Gemma A, Kudoh S, Croce CM and Harris CC: MiR-21 is an EGFRregulated anti-apoptotic factor in lung cancer in never-smokers. Proc Natl Acad Sci USA 106: 12085-12090, 2009.

21. Satelli A and Li S: Vimentin in cancer and its potential as a molecular target for cancer therapy. Cell Mol Life Sci 68: 3033-3046, 2011.

22. Sobin LH and Wittekind C (eds): TNM classification of malignant tumours. In: International Union Against Cancer (UICC). 6th edition. John Wiley \& Sons, Hoboken, NJ, pp255$257,2009$.

23. Nohata N, Hanazawa T, Kikkawa N, Mutallip M, Fujimaru L, Yoshino H, Kawakami K, Chiyomaru T, Enokida H, Nakagawa M, Okamoto T and Seki N: Caveolin-1 mediates tumor cell migration and invasion and its regulation by miR-133a in head and neck squamous cell carcinoma. Int J Oncol 38: 209-217, 2011.

24. Nohata N, Sone Y, Hanazawa T, Fuse M, Kikkawa N, Yoshino H, Chiyomaru T, Kawakami K, Enokida H, Nakagawa M, Shozu M, Okamoto T and Seki N: miR-1 as a tumor suppressive microRNA targeting TAGLN2 in head and neck squamous cell carcinoma. Oncotarget 2: 29-44, 2011
25. Siegel R, Naishadham D and Jemal A: Cancer statistics, 2012. CA Cancer J Clin 62: 10-29, 2012.

26. Friedl $\mathrm{P}$ and Alexander S: Cancer invasion and the microenvironment: plasticity and reciprocity. Cell 147: 992-1009, 2011.

27. Soini Y: Tight junctions in lung cancer and lung metastasis: a review. Int J Clin Exp Pathol 5: 126-136, 2012.

28. Brabletz S and Brabletz T: The ZEB/miR-200 feedback loop - a motor of cellular plasticity in development and cancer? EMBO Rep 11: 670-677, 2010.

29. Mongroo PS and Rustgi AK: The role of the miR-200 family in epithelial-mesenchymal transition. Cancer Biol Ther 10: 219-222, 2010

30. Li X, Jiang L, Wang A, Yu J, Shi F and Zhou X: MicroRNA-138 suppresses invasion and promotes apoptosis in head and neck squamous cell lines. Cancer Lett 286: 217-222, 2009.

31. Hogg RP, Honorio S, Martinez A, Agathanggelou A, Dallol A, Fullwood P, Weichselbaum R, Kuo MJ, Maher ER and Latif F: Frequent $3 p$ allele loss and epigenetic inactivation of the RASSF1A tumour suppressor gene from region 3p21.3 in head and neck squamous cell carcinoma: Eur J Cancer 38: 1585-1592, 2002.

32. Sukosd F, Kuroda N, Beothe T, Kaur AP and Kovacs G: Deletion of chromosome 3p14.2-p25 involving the VHL and FHIT genes in conbentional renal cell carcinoma. Cancer Res 63: 455-457, 2003.

33. Jiang L, Liu X, Kolokythas A, Yu J, Wang A, Heidbreder CE, Shi $F$ and Zhou X: Downregulation of the Rho GTPase signaling pathway is involved in the microRNA-138-mediated inhibition of cell migration and invasion in tongue squamous cell carcinoma. Int J Cancer 127: 505-512, 2010.

34. Liu X, Wang C, Chen Z, Jin Y, Wang Y, Kolokythas A, Dai Y and Zhou X: MicroRNA-138 suppresses epithelial-mesenchymal transition in squamous cell carcinoma cell lines. Biochem J 440: 23-31, 2011.

35. Wang W, Zhao LJ, Tan YX, Ren H and Qi ZT: Mir-138 induces cell cycle arrest by targeting cyclin D3 in hepatocellular carcinoma. Carcinogenesis 33: 1113-1120, 2012.

36. Young AN, Amin MB, Moreno CS, Lim SD, Cohen C, Petros JA, Marshall FF and Neish AS: Expression profiling of renal epithelial neoplasms: a method for tumor classification and discovery of diagnostic molecular markers. Am J Pathol 158: 1639-1651, 2001

37. Williams AA, Higgins JP, Zhao H, Ljunberg B and Brooks JD CD9 and vimentin distinguish clear cell from chromophobe renal cell carcinoma. BMC Clin Pathol 9: 9, 2009. 